 \\ Erratum}

https://doi.org/10.11646/zootaxa.5027.4.9

http://zoobank.org/urn:lsid:zoobank.org:pub:99521A77-B6AB-4D21-83D1-E8223D17E435

\title{
STEPHEN J. MAXWELL, TASMIN L. RYMER \& BRADLEY C. CONGDON (2021) Resolving phylogenetic and classical nomenclature: A revision of Seraphsidae Jung, 1974 (Gastropoda: \\ Neostromboidae). Zootaxa, 4990: 401-453.
}

Page 406, Taxonomy, line 6 : The "Seraphsidae Gray, 1853" should read "Seraphsidae Jung, 1974". The authors thank Aart Dekkers for pointing out this error.

Page 425, The type genus for Pseudoterebellinae new subfamily is "Pseudoterebellum new genus" and not "Terebellum Röding, 1798". 